\title{
РАСПРЕДЕЛЕНИЕ ДИКТИОНЕМОВОГО СЛАНЦА И ТЕМПЕРАТУРНЫЙ РЕЖИМ ЕГО САМОНАГРЕВА В ОТВАЛАХ МААРДУСКОГО ФОСФОРИТНОГО КАРЬЕРА
}

При разработке Маардуского фосфоритного месторождения во внутренние отвалы карьера ежегодно перемещается около 2,5 млн. $T$ керогенсодержащего металлоносного аргиллита - диктионемового сланца пакерортского горизонта нижнего ордовика (в дальнейшем просто сланца). Этот сланец, являясь потенциальным энергетическим и химическим сырьем (Альтгаузен, Маремяэ, 1980; Лаус, Эленурм, 1963), теряется безвозвратно. При доступе кислорода воздуха органическое вещество сланца окисляется, что приводит к самонагреву и при благоприятных условиях к самовозгоранию сланца (Альтгаузен, Маремяэ, 1980; Наумов, 1981). Очаги горения сланца поражают лесопосаджи на рекультивированных площадях (Наумов, 1981). Установлено загрязнение карьерных вод в результате выщелачивания и атмосферы при самонагреве и самовозгорании сланца.

Эти обстоятельства, которые служат внешним проявлением скрытых, пока слабо исследованных тепловых процессов, совершенно не изученных во времени и пространстве, а также факт, что торные разработки ведутся в зеленой зоне города Таллина, послужили основанием для исследования динамики температурного режима горных пород в отвальном пространстве фосфоритного карьера.

Наблюдения, проведенные в карьере Маарду, выявили две температурные зоны, формирующиеся в результате окисления сланца в отвальной толще. Высокотемпературная зона тяготеет к поверхности отвалов - она прерывиста и приурочена к отдельным очагам горения. Эта зона наиболее обеспечена притоком кислорода воздуха и относительно легко доступна.для изучения. Здесь наблюдается горение сланца с температурой отдельных очагов до $800^{\circ} \mathrm{C}$ и выделением значительного количества двуокиси серы и других газов. Очаги горения и высокотемпературные участки в дальнейшем обозначаются как активные.

Низкотемпературная зона охватывает всю толщу отвала и характеризуется медленным окислением сланца, проходящем в основном в условиях недостатка кислорода и при температуре ниже $80-70^{\circ}$. Площади без признаков горения и высокотемпературного окисления ниже обозначаются как пассивные. Многолетние наблюдения процессов самонагрева и горения показали, что высокотемпературные очаги развиваются в течение $0,25-1$ года (при наличии благоприятных условий) и прогорают за $1-3$ года в основном при температуре $200-300^{\circ}$ (редко $800^{\circ}$ ). Темпы роста температуры в ореднем составляют $1-2^{\circ}$ в сутки, темпы падения температуры - от 0,1 до $4-7^{\circ}$ в сутки. Соответствующие показатели для низкотемпературных процессов гораздо ниже. В связи с тем, что в очагах горения в высокотемпературном изменении принимает участие вся находящаяся там масса сланца, на месте бывших очагов можно выделить новообразованную инертную, неспособную к самонагреву зону. Очевидно, что в смешанном известняково-сланце- 

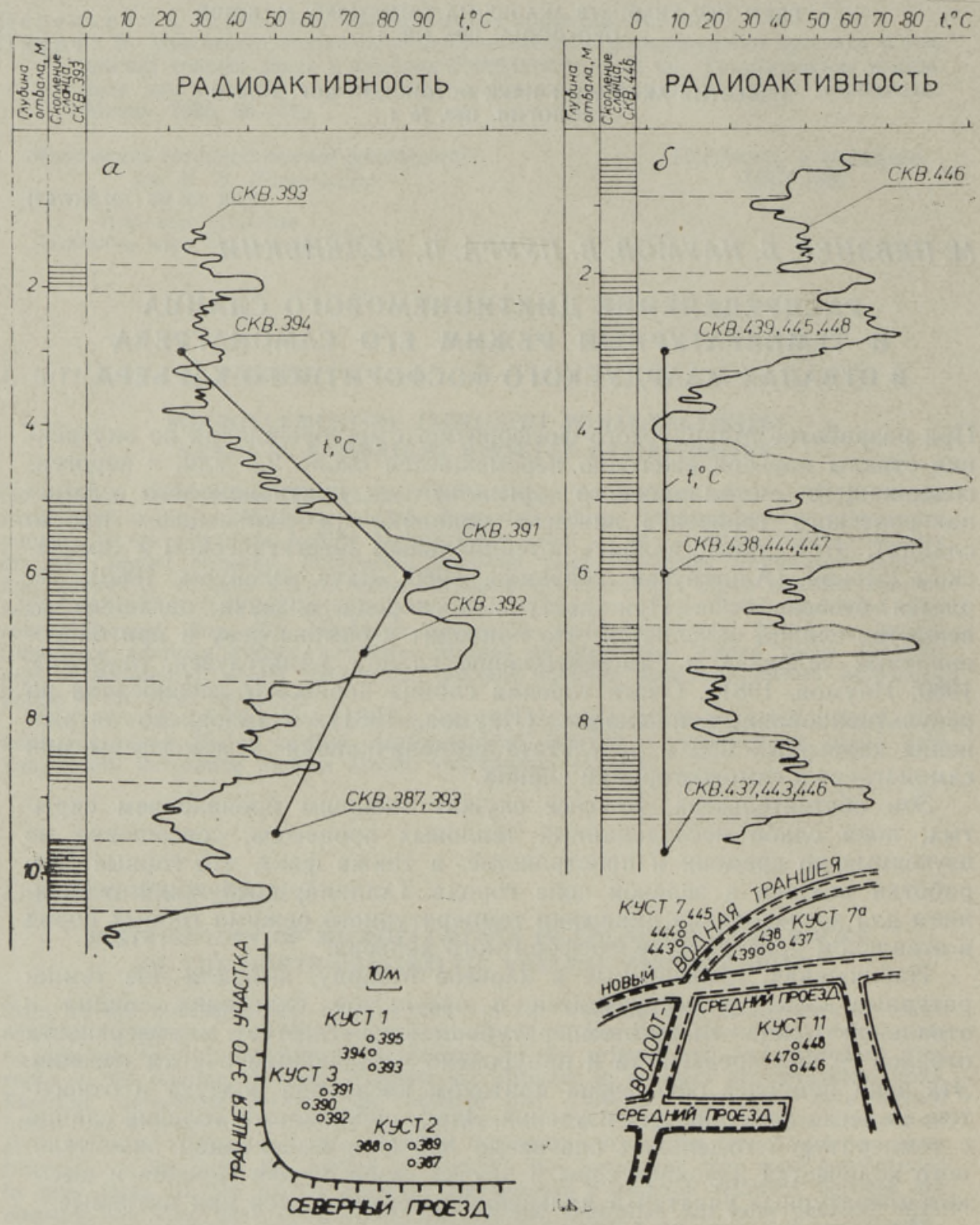

Рис. 1. Распределение диктионемового сланца в отвале (по данным радиоактивного каротажа) и температура отвальной массы по замерам на площадях: а) с активным прогревом и б) с объемным заиливанием глиннстыми породами.

вом отвале такая зона формируется и в случае низкотемпературного окисления. Время формирования такой зоны зависит от того, в какой комбинации и насколько полно реализуются процессы окисления при разных температуре и скорости. С точки зрения охраны окружающей среды недопустимы как процессы выщелачивания в целом, так и высокотемпературный нагрев. Для сохранения сланца в качестве сырьевого и энергетического ресурса, а также для максимально возможного снижения запрязнения подземных вод выщелачивающимися компонентами необходимо затормозить также процесс низкотемпературного окисления. Для изучения закономерностей распределения сланца и исследо- 
Распределение диктионемового сланца по глубине отвальной массы по данным радиоактивного каротажа, \%

(в числителе - среднее арифметическое, в знаменателе - интервал колебаний)

\begin{tabular}{|c|c|c|c|c|c|c|c|c|c|}
\hline \multirow[b]{2}{*}{$\begin{array}{l}\text { Интер- } \\
\text { вал } \\
\text { глубины } \\
\text { от по- } \\
\text { верхно- } \\
\text { сти, } М\end{array}$} & \multirow[b]{2}{*}{ 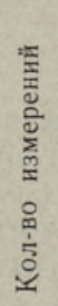 } & \multicolumn{4}{|c|}{ Доля сланца } & \multicolumn{4}{|c|}{$\begin{array}{c}\text { Распределение сланща } \\
\text { в толще отвала }\end{array}$} \\
\hline & & $\begin{array}{l}\text { В целом } \\
\text { по отвалам }\end{array}$ & $\begin{array}{c}\text { На ак- } \\
\text { тивных } \\
\text { площа- } \\
\text { дях }\end{array}$ & $\begin{array}{c}\text { На пас- } \\
\text { сивных } \\
\text { площа- } \\
\text { дях }\end{array}$ & $\begin{array}{c}\text { На } \\
\text { участ- } \\
\text { ках с } \\
\text { глинис- } \\
\text { тым } \\
\text { заили- } \\
\text { ванием }\end{array}$ & $\begin{array}{c}\text { В целом } \\
\text { по } \\
\text { отва- } \\
\text { лам }\end{array}$ & $\begin{array}{c}\text { На ак- } \\
\text { тивных } \\
\text { площа- } \\
\text { дях }\end{array}$ & $\begin{array}{c}\text { На пас- } \\
\text { сивных } \\
\text { площа- } \\
\text { дях }\end{array}$ & \begin{tabular}{|c} 
На \\
участ- \\
ках с \\
глинис- \\
тым \\
заили- \\
ванием
\end{tabular} \\
\hline $\begin{array}{l}\text { Кол-во } \\
\text { скважин }\end{array}$ & & 18 & 6 & 9 & 3 & 18 & 6 & 9 & 3 \\
\hline$c-1$ & 18 & $\frac{16,8}{0-80}$ & 0 & 20 & 52,5 & 3,3 & 0 & 4 & 20,4 \\
\hline $1-3$ & 18 & $\frac{30,3}{0-72,5}$ & 25,5 & 33,3 & 37,5 & 6 & 6,8 & 6,7 & 14,5 \\
\hline $3-5$ & 18 & $\frac{36.5}{0-75}$ & 25 & 42,2 & 55 & 7,2 & 6,6 & 8,5 & 21,2 \\
\hline $5-7$ & 16 & $\frac{54,4}{\mathrm{c}-100}$ & 62,5 & 49,7 & 70 & 10,8 & 16,6 & 10 & 27 \\
\hline $7-9$ & 16 & $\frac{50,8}{0-100}$ & 39,3 & 56,5 & 43,8 & 10,1 & 10,4 & 11,4 & 16,9 \\
\hline $9-11$ & 14 & $\frac{54,8}{0-100}$ & 25 & 44,2 & - & 10,9 & 6,6 & 8,9 & - \\
\hline $11-13$ & 9 & $\frac{39,3}{0-60}$ & 18,8 & 46,1 & - & 7,8 & 5 & 9,3 & - \\
\hline $13-15$ & 8 & $\frac{38,5}{0-75}$ & 70 & 30,6 & - & 7,6 & 18,6 & 6,2 & - \\
\hline $15-17$ & 6 & $\frac{48,8}{0-100}$ & 10 & 61,7 & - & 9,7 & 2,8 & 12,4 & - \\
\hline $17-19$ & 4 & $\frac{56,7}{20-100}$ & 100 & 35 & - & 11,2 & 26,6 & 7 & - \\
\hline $19-21$ & 3 & $\frac{77,5}{60-95}$ & - & 77,5 & - & 15,4 & - & 15,6 & - \\
\hline
\end{tabular}

вания температурной динамики отвальной массы на отработанных площадях Маардуского фосфоритного рудника в 1980 г. Госгорхимпроектом пробурено 25 кустов наблюдательных скважин. Қаждый куст состоит из трех скважин, удаленных друг от друга на $3-4$ м. Их глубина 2,5-21 м. Скважины оборудованы обсадными трубами с фильтрами в нижней части, устье труб закрыто заглушками, затрубное пространство заполнено глинистым материалом. В каждом кусте первая из скважин вскрывает верхнюю, потенциально активную часть отвала $(2,5-5$ м ), вторая - половину его высоты $(7-10$ м) и третья - полную высоту $(15-21$ м). В плане кусты расположены так, чтобы возможно было получить информацию о состоянии отвальной массы: a) по годам отработки, начиная с 1965 г., б) по площадям с разной интенсивностью самонагрева и в) в местах, где сланец складирован с применением глинистых заиливающих пород в добычных траншеях (при отработке заболоченных площадей) . 
В охваченном скважинами районе карьера Маарду разрез пород, перекрывающих фосфоритный слой, следующий (снизу вверх);

кварцевый оболовый песчаник - 2,5 м
диктионемовый сланец - 2,5-3,
пзвестняки - до $5-7, \mu$,
четвертичные отложения - $0,5-3 м$.

В северной части карьера диктионемовый сланец составляет 25-40, а в южной - 27-33\% объема отвалыных пород. С точки зрения возможности конструирования отвала для предупреждения самовозгорания, интерес представляют распространенные местами четвертичные глинистые отложения, которые могут служить надежным изолирующим доступ кислорода воздуха материалом.

Поскольку получение полного керна при бурении было сложно, для изучения распределения сланца в отвале Кейлаской геологической экспедицией УГ ЭССР (И. Лухт, В. Мусиенко) был произведен радиоактивный каротаж наиболее глубоких скважин 18 кустов на отвалах и для контроля одной скважины, пробуренной в целике. Полученные данные позволили достаточно точно и легко определить глубину и мощность скоплений сланца на фоне известняков и доломитов ордовика и четвертичных отложений, совместно со сланцем формирующих вскрышу фосфоритного пласта, а также долю сланца в том или ином интервале глубины и в отвальной массе в целом (рис. 1; табл. 1). Идентификация скоплений сланца на графике каротажа проводилась по характерным пикам радиоактивности, мощность определялась по шкале глубин. При этом предполагалось, что влияние глауконитового песчаника, дающего несколько отличную от фона радиоактивность, незначительно из-за его более равномерного рассредоточения в массе отвальных пород по причине малой прочности и способности рассыпаться при экскавации.

Обработка геологической и горнотехнологической документаций позволила продублировать эти результаты. Фотопланиметрическим (стереологическим) методом было изучено распределение горной массы в соответствии с фракционным составом в теле отвала при экскавации пород. Расчеты показывают, что полученные каротажем ориентировочные данные о линейном распределении сланца в околоскважинном пространстве соответствуют балансу отвальных пород.

Для выявления зависимости температуры отвальной толщи от мощности, содержания и глубины размещения скоплений сланца с ноября 1980 по сентябрь 1981 г. проведено около 300 замеров температуры (рис. 2). Каждый замер отражал температуру забоя скважины на определенной глубине, обобщенно характеризуя, таким образом, состояние данной толщи отвала. Для каждого куста проведено $4-5$ циклов наблюдений. Последний цикл, состоящий из 56 замеров (сентябрь 1981 г.), не показал сколько-нибудь значительных отклонений от результатов предыдущих циклов.

Фиксировались также уровень и мощность слоя грунтовых вод. Замер температур производился ртутным термометром, помещенным в металлический патрон с прорезью для взятия отсчета. Тепловая инерция термометра составляла $0,1-0,2$ град/мин. Время извлечения термометра со дна самой глубокой скважины - 0,5 мин.

Основные специфические закономерности состояния отвальной массы во времени и пространстве следующие.

При валовой экскавации пород вскрыши и неуправляемом отвалообразовании после планировки отвалов около $1 / 3$ (до $34,9 \%$ ) сланца оказывается на глубине $0-3$ м (в среднем на глубине 1,64 м) от днев- 

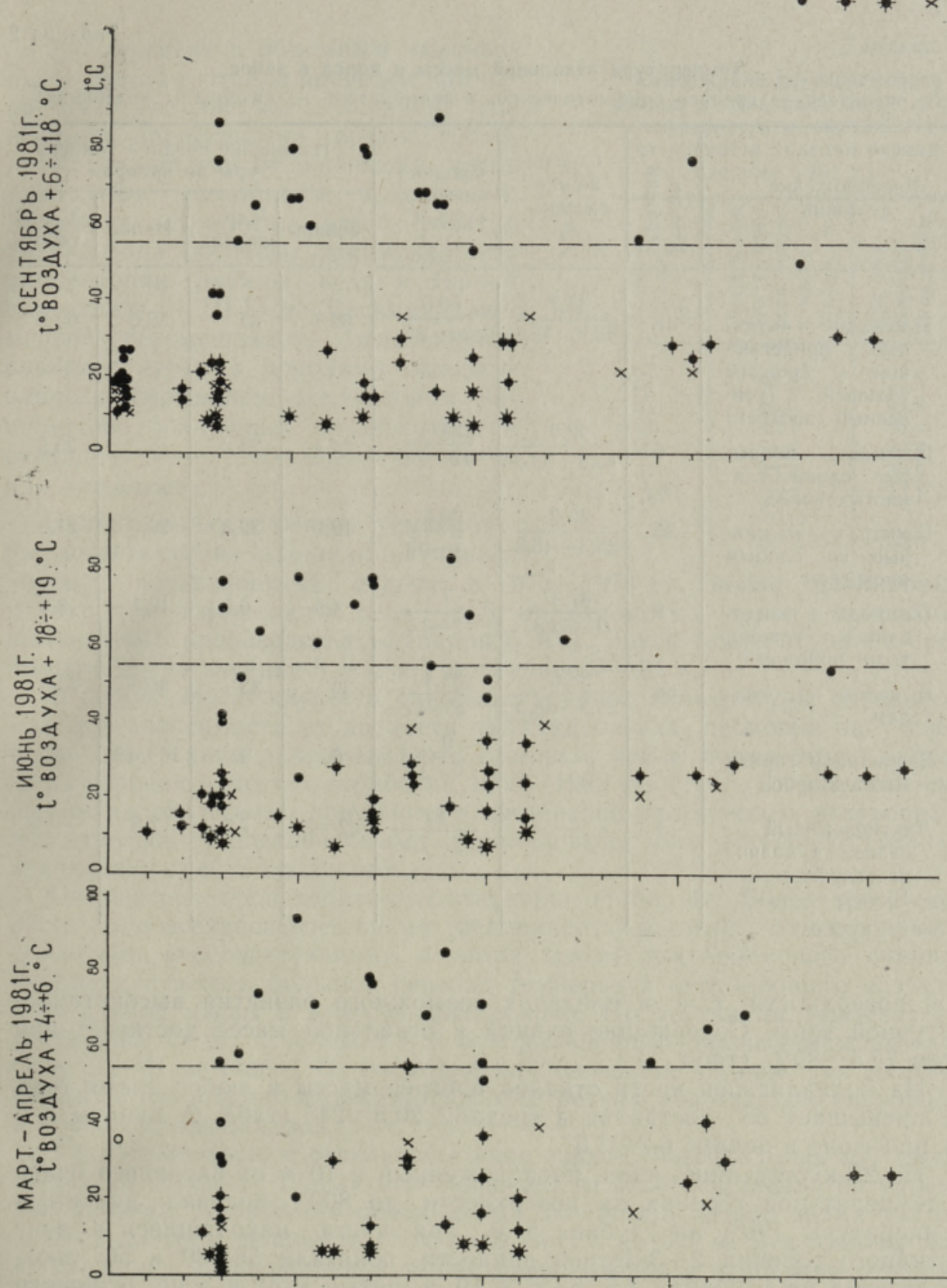

늠

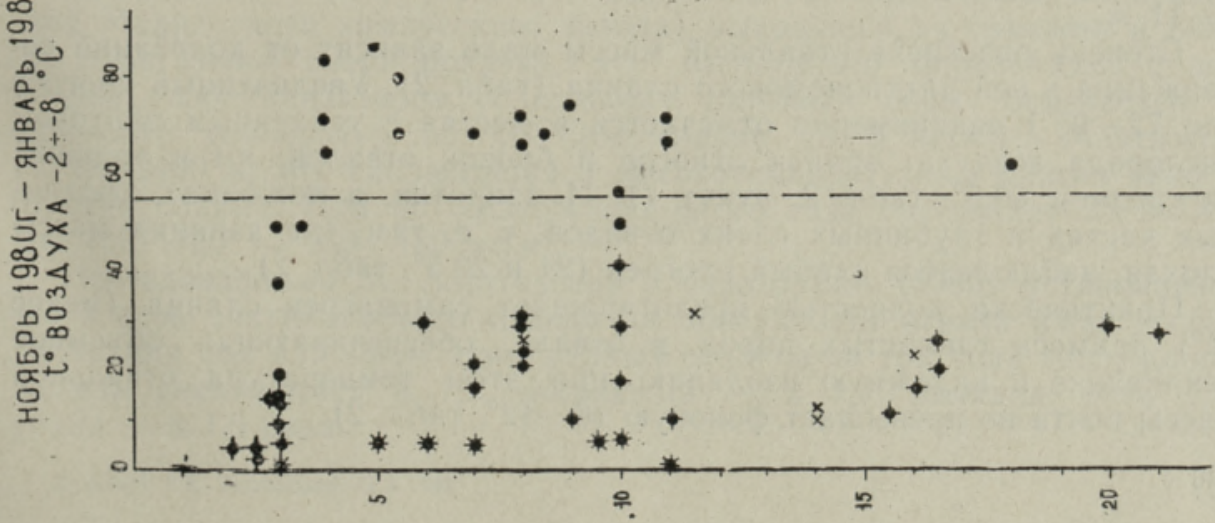

W' 
Температура отвальной массы и пород в забое

(в числителе - среднее арифметическое, в знаменателе - интервалы колебания)

\begin{tabular}{|c|c|c|c|c|c|c|c|}
\hline \multirow{2}{*}{$\begin{array}{l}\text { Расположение } \\
\text { скважин }\end{array}$} & \multirow{2}{*}{ 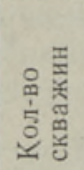 } & \multirow{2}{*}{$\begin{array}{c}\text { Содер- } \\
\text { жание } \\
\text { сланца, } \\
\%\end{array}$} & \multirow{2}{*}{$\begin{array}{l}\text { Средняя } \\
\text { темпера- } \\
\text { тура, }{ }^{\circ} \mathrm{C}\end{array}$} & \multicolumn{4}{|c|}{$\begin{array}{c}\text { Изменение средней темпера- } \\
\text { туры во времени }\end{array}$} \\
\hline & & & & Январь & $\begin{array}{l}\text { Март- } \\
\text { апрельь }\end{array}$ & Июнь & $\begin{array}{l}\text { Сен- } \\
\text { тябрь }\end{array}$ \\
\hline $\begin{array}{l}\text { 1. Площади актив- } \\
\text { ные, прилегаю- } \\
\text { щие к бровкам } \\
\text { траншей (уси- } \\
\text { ленный прогрев) }\end{array}$ & 18 & $\frac{35,7}{30,3-42,1}$ & $\frac{60.5}{20+95}$ & 62,7 & 61 & 58,6 & 65,2 \\
\hline $\begin{array}{l}\text { 2. Площади, покры- } \\
\text { тые слоем гли- } \\
\text { нистых пород }\end{array}$ & 6 & $\frac{49.4}{45,6-53,3}$ & $\frac{24}{12-39}$ & 21,4 & 24,6 & 25,7 & 25,5 \\
\hline $\begin{array}{l}\text { 3. Площади пассив- } \\
\text { ные, со слабым } \\
\text { прогревом }\end{array}$ & 35 & $\frac{38.2}{25,3-46,3}$ & $\frac{20,5}{1-55}$ & 19,0 & 22,3 & 20,3 & 21,8 \\
\hline $\begin{array}{l}\text { 4. Площади с занли- } \\
\text { ванием глинис- } \\
\text { тыми породами }\end{array}$ & 9 & $\frac{47,4}{0-52,8}$ & $\frac{7}{2-14}$ & 4,5 & 6,1 & 10,1 & 8,9 \\
\hline $\begin{array}{l}\text { 5. В целом по отва- } \\
\text { лам }\end{array}$ & 68 & $\frac{38,6}{25,3-53,3}$ & $\frac{31.4}{2-95}$ & 30 & 33 & 30,9 & 33,3 \\
\hline $\begin{array}{c}\text { 6. Взорванная горная } \\
\text { масса в забое }\end{array}$ & - & - & $\frac{9}{6-12}$ & 6 & 9 & $10-12$ & - \\
\hline $\begin{array}{l}\text { 7. Диктионемовый } \\
\text { сланец в целике } \\
\text { на глубине 6- } \\
10 \text { м }\end{array}$ & 1 & - & $\frac{7,12}{6,2-7,5}$ & $6,2-7$ & 7,3 & 7,5 & - \\
\hline
\end{tabular}

ной поверхности, т. е. в пределах возможного развития высокотемпературной зоны. Содержание сланца в отвальной массе достигает при этом $72,5-80 \%$ (табл. 1 ).

На подавляющей части отвалов прогрев массы в любое время года не превышает $55^{\circ}$, составляя в среднем 20,5-24 (табл. 2, пункты 2 и 3) при фоне в целике $6,2-7,5^{\circ}$.

Из 25 кустов лишь один, расположенный в 10 о от активного очага с температурой горения на поверхности до $800^{\circ}$, показал максимум температуры $\left(95^{\circ}\right)$ на глубине 5 . Три куста, находящиеся в зоне активного горения $2-3$-летней давности, показали 58,80 и $56^{\circ}$ cootветственно на глубинах $3,5,5-6$ и 10 м, пятый куст.в зоне активного горения старого отвала (12-летней давности) - $68-72^{\circ}$ на глубине $8-11 \mu$.

Степень разогрева отвальной массы мало зависит от колебаний содержания в ней диктионемового сланца (табл. 2). Увеличенный прогрев (до $72-95^{\circ}$ ) закономерно отмечается в местах с усиленным притоком кислорода воздуха: вблизи откосов и бровок отвалов, ям и траншей (в среднем $60,5^{\circ}$, табл. 2 , пункт 1 ). И напротив, в ложбинах, орединных частях и глубинных слоях отвалов, т. е. там, где аэрация массы плохая, наблюдается слабый прогрев (24 и 20,5, табл. 2).

Практически полностью предотвращает самонагрев сланца (менее $14^{\circ}$ ) примесь глинистых пород в отвале, обеспечивающая объемное заиливание и надежную изоляцию, при этом температура отвальной массы почти не превышает фоновую (6-12², табл. 2$)$. 
Эксперимент с объемным заиливаТаблица 3 нием сланца в отвале проведен при отработке болотистых площадей, где вскрыша представлена торфом, гравелисто-глинистыми отложениями, глауконитовым песчаником и сланцем. Методика отработки этого участка разработана согласно рекомендациям лаборатории охраны недр и горной геомеханики ГИГХСа. Весьма равномерное перемешивание отдельностей сланца с другими породами осуществлялось вскрышным экскаватором. Заполнению воздушных промежутков в отвальной массе способствовала высокая влажность.

Значительное снижение температуры достигнуто на площади активного

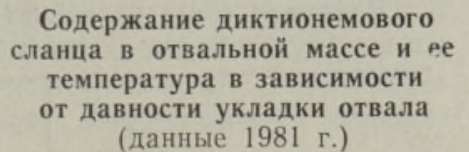

\begin{tabular}{|c|c|c|}
\hline 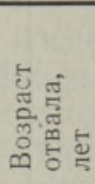 & 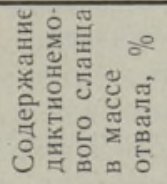 & 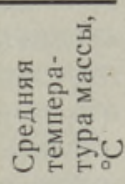 \\
\hline $\begin{array}{l}16 \\
15 \\
12 \\
11 \\
5 \\
3,5\end{array}$ & $\begin{array}{c}41,2 \\
45,6 \\
42,1 \\
35,2 \\
33,3 \\
30,9 \\
\text { около }\end{array}$ & $\begin{array}{l}21,2 \\
28,9 \\
56,4 \\
22,9 \\
39,5 \\
37,1\end{array}$ \\
\hline 2 & $25-30$ & 25,2 \\
\hline
\end{tabular}
горения поверхностных очагов в 1972-1974 гг. после планировки и покрытия поверхности слоем $(0,5$ м) глинистых пород - отходов щебеночного производства (фракция 5 мм). Здесь температура не превышает $21^{\circ}$ на глубине $3 \mu$ и $39^{\circ}$ на глубине $7-10 \mu$.

В целом прослеживается снижение средней температуры отвальной массы в зависимости от давности укладки отвала, неомотря на увеличение содержания диктионемового сланца в нем и повышенную активность горения в местах отработки 1966-1969 гг. (табл. 3), обусловленных технологическими причинами (применение маломощных вскрышных экскаваторов с опраниченными параметрами, многолетнее отставание планировки гребней отвалов).

Самонагрев происходит круглогодично (табл. 4). Более того, скорость его в осенне-зимнее время увеличивается в связи с атмосферными условиями, способствующими аэрации массы диктионемового сланца, такими как ветры, большой перепад температур окружающего воздуха и отвальной массы и атмосферные осадки. По вертикали температура увеличивается до глубины 9-14 м с дальнейшим понижением на глубине $16-21 м$ (табл. 4), несмотря на повышение содержания диктионемового сланца, что объясняется более резким недостатком кислорода в нижних слоях отвалов.

Грунтовые воды в отвальной толще зафиксированы лишь в 7 скважинах на глубинах $19-21$ м от поверхности непосредственно на уровне дна карьера. Количество обводненных скважин в летнее время уменьшилось до трех, мощность слоя воды от 1,5 до $0,5 \mu$. Все выходы вод из отвалов в виде родников также расположены в основании отвалов. Температура выходящих из отвалов вод колеблется от 14 до $30^{\circ}$.

Химический анализ (проведен совместно с санитарной лабораторией Маардуского химического завода) выходящей из скважин и очагов парогазовой смеси показал, что минимально определимое с помощью газоанализаторов содержание двуокиси серы отмечается в интервале температур $55-66^{\circ}$ (от следов до $5 \mathrm{~m} / \mathrm{M}^{3}$ ). Максимум $\left(1200-2400 \mathrm{mz} / \mathrm{m}^{3}\right)$ наблюдается в высокотемпературных очагах явного горения сланца. При $90^{\circ}$ содержание этого газа составляет $25 \mathrm{mz} / \mathrm{m}^{3}$, при $100-120^{\circ}-130-180 \mathrm{мг} / \mathrm{M}^{3}$.

Исследованиями М. Альтгаузена с соавторами (1980) установлено, что в слое диктионемового сланца на поверхности отвала из-за выщелачивания под влиянием атмосферных осадков за три года содержание железа уменьшается в 1,2 , молибдена — в 1,1 , ванадия - в 1,2 , урана - в 1,5 раза. 
Динамика средней температуры отвальной массы во времени и в пространстве (в числителе - температура, ${ }^{\circ} \mathrm{C}$, в знаменателе - количество измерений)

\begin{tabular}{|c|c|c|c|c|c|c|c|}
\hline \multirow[b]{2}{*}{$\begin{array}{l}\text { Тип отвальных } \\
\text { площадей }\end{array}$} & \multicolumn{4}{|c|}{ Во времени } & \multicolumn{3}{|c|}{$\begin{array}{l}\text { В пространстве } \\
\text { (по вертикали) }\end{array}$} \\
\hline & Январь & $\begin{array}{l}\text { Март- } \\
\text { апрель }\end{array}$ & Июнь & $\begin{array}{l}\text { Сен- } \\
\text { тябрь }\end{array}$ & $\begin{array}{c}\text { Глубина } \\
\text { замера, } \\
M\end{array}$ & $\begin{array}{l}\text { Коли- } \\
\text { чество } \\
\text { изме- } \\
\text { рений }\end{array}$ & $\begin{array}{l}\text { Teмne- } \\
\text { parypa, } \\
{ }^{\circ} \mathrm{C}\end{array}$ \\
\hline Пассивные площади: & & & & & & & \\
\hline $\begin{array}{l}\text { С глинистым заилива- } \\
\text { нием }\end{array}$ & $\frac{4,5}{9}$ & $\frac{6,1}{9}$ & $\frac{10.1}{9}$ & $\frac{8,9}{9}$ & $\begin{array}{l}2-3 \\
5-7 \\
9-11\end{array}$ & $\begin{array}{l}12 \\
12 \\
12\end{array}$ & $\begin{array}{l}5,2 \\
8,1 \\
7,2\end{array}$ \\
\hline $\begin{array}{ll}\text { Покрытые } & \text { отходами } \\
\text { щебеночного } & \text { пронзвод- } \\
\text { ства } & \end{array}$ & $\frac{21,4}{6}$ & $\frac{24,6}{6}$ & $\frac{25,7}{6}$ & $\frac{25,5}{6}$ & $\begin{array}{c}3 \\
8 \\
11-12 \\
14-16\end{array}$ & $\begin{array}{l}5 \\
5 \\
6 \\
8\end{array}$ & $\begin{array}{l}15,5 \\
33,3 \\
36,7 \\
18,7\end{array}$ \\
\hline $\begin{array}{l}\text { Остальные, со слабым } \\
\text { прогревом }\end{array}$ & $\frac{19}{25}$ & $\frac{22,3}{24}$ & $\frac{20,3}{35}$ & $\frac{21,8}{24}$ & $\begin{array}{c}2 \\
3 \\
5-8 \\
9-11 \\
14-17 \\
19-21\end{array}$ & $\begin{array}{r}9 \\
20 \\
28 \\
25 \\
15 \\
9\end{array}$ & $\begin{array}{l}12,2 \\
16,6 \\
19,0 \\
22,6 \\
25,0 \\
27,0\end{array}$ \\
\hline $\begin{array}{l}\text { Активные площади: } \\
\text { С усиленным прогре- } \\
\text { вом }\end{array}$ & $\frac{62,7}{16}$ & $\frac{61}{19}$ & $\frac{58,6}{21}$ & $\frac{65,2}{17}$ & $\begin{array}{c}3-4 \\
5-6 \\
7-10 \\
11-17 \\
18 \\
19\end{array}$ & $\begin{array}{r}24 \\
12 \\
24 \\
9 \\
2 \\
2\end{array}$ & $\begin{array}{l}51,0 \\
65,4 \\
68,7 \\
63,1 \\
62,0 \\
54,0\end{array}$ \\
\hline $\begin{array}{l}\text { В среднем по всем сква- } \\
\text { жинам }\end{array}$ & $\frac{30}{56}$ & $\frac{33}{58}$ & $\frac{30,9}{71}$ & $\frac{33,3}{56}$ & $\begin{array}{c}2 \\
3-4 \\
5-7 \\
9-11 \\
14-16 \\
19-21\end{array}$ & $\begin{array}{l}16 \\
55 \\
57 \\
49 \\
32 \\
11\end{array}$ & $\begin{array}{l}22,8 \\
26,9 \\
29,8 \\
38,0 \\
34,1 \\
27,4\end{array}$ \\
\hline
\end{tabular}

Растворы сульфатов железа выщелачивают до 9-39\% вышеназванных элементов. Содержание же сульфатной серы, являющейся продуктом окисления пирита, с уменьшением содержания кислорода на глубине от 0,3 до 1,8 м уменышается в 5,2 раза $(2,6-0,5 \%)$.

Отсюда следует, что при относительно низких температурах количество выщелачивающихся элементов даже на малой глубине резко уменьшается из-за снижения скорости окисления серы и образования сульфатов железа. Это подтверждается и тем, что содержание ионов $\mathrm{SO}_{4}{ }^{-2}$ в водах, вытекающих из-под негорящих отвалов, в 8,3 раза меньше, чем в водах, вытекающих из-под горящих отвалов: 419,4 против 3468 мг/л. Содержание $\mathrm{SO}_{4}^{-2}$ в воде озера Маарду 270 мг/л (данные ГИГХСа). Предельно допустимая концентрация $\mathrm{SO}_{4}^{-2}$ для водоема $500 \mathrm{M2} / \Omega$.

\section{Выводы}

1. Радиоактивный каротаж скважин, фотопланиметрия и анализ геологической и технологической документаций позволяют с достаточной степенью точности изучить перераспределение диктионемового сланца, происходящее в процессе горных работ, как в целом по площади, так и по разрезу отвальной толщи. При необходимости радиоактивный каротаж скважин позволяет контролировать соблюдение технологии укладки диктионемового сланца в отвале. 
2. Для предотвращения загрязнения окружающей среды выделяющимися в основном при высокотемпературном окислении сланца газами и растворами необходимо обеспечить надежную изоляцию складируемого объема диктионемового сланца инертными материалами. При этом объемная (сплошная или послойная) изоляция эффективнее поверхностной.

3. Предельно допустимым напревом горной массы, следует считать 50 - $60^{\circ}$. Выше этого предела начинается заметное выделение сернистого газа. Для полного предотвращения окисления сланца и сохранения его в качестве вторичного сырьевого и энергоресурса необходимо соблюдать весьма жесткие требования к консервации этого полезного ископаемого.

\section{ЛИТЕРА Т У Р А}

Альтгаузен М., М аремяэ $Э .$, Иоханнес $Э .$, Липпма а $Э$. Гипергенное разложение черных металлоносных сланцев. - Изв. АН ЭССР. Хим., 1980, $29,165-166$.

Л ау с Т. Н., Элен урм А. А., Кылль А. Т., Губергриц М. Я. О двухступенчатой термической переработке диктионемового сланца. - Энерготехн. использ. топлива. М., 1963, вып. 4, 148-152.

Н а ум в Б. Е. Основные закономерности процесса аутогенного нагрева диктионемового сланца в отвалах Маардуского фосфоритного рудника. - В кн.: Проблемы горной экологии. Тр. ГИГХС, вып. 53, М., 1981, 59-63.

Н а ум о Б. Е. Проблемы предупреждения самовозгорания диктионемового сланца при разработке фосфоритных месторождений Прибалтики. - Тез. докл. и сообщ. на совещ. «Проблемы снижения вредного влияния горных работ на окружающую среду». М., 1980, 73-76.

П в в не р М. Е. Горная экология - новое направление в горной науке. - В кн.: Проблемы охраны недр, геомеханики и геотехнологии в горнохимической промышленности. Тр. ГИГХС, вып. 41, ч. I. М., 1977.

Предельно допустимые концентрации вредных веществ в воздухе и воде. Л., 1975.

Государственный институт горнохимического сырья (ГИГХС)

Ннститут геологии

Академии наук Эстонской ССР
Поступила в редакцию 2/XII 1981

\section{PEVZNER, B. NAUMOV, V. PUURA, A. BELENKI}

\section{MAARDU FOSFORIIDIKARJÄARI PUISTANGUTE DIKTUONEEMAKILDA JAOTUS JA ISEENESLIKU SOOJENEMISE TEMPERATUURIREZIIM}

Umbes $1 / 3$ diktüoneemakilta (kerogeeni sisaldavat argilliiti) satub kaevandamisel $0-3$ m sügavusse, ülejäänu jaotub kogu puistangu läbilōikes, s. o. kattekihtide paksúsest olenevalt 5-10 kuni 15-20 m-ni. Puuraukude temperatuuri mõōtmisest järeldub, et diktüoneemakilda kerogeeni oksüdeerumisest tingituna soojeneb kogu mäemass aastaajast sôltumata. Isesoojenemise režiim oleneb aeratsioonitingimustest, soodsates oludes vôib temperatuur kogu puistangu läbilōikes tōusta 55 , erandina isegi $95^{\circ}-n i$ C. Isesüttimist (temperatuur kuni $800^{\circ} \mathrm{C}$ ) esineb pindmises kihis. Puistangu katmine tihendatud killustikujäätmetega, eriti aga kogu massi segamine savisetetega pidurdab soojenemist ja on seni vältinud isesüttimist.

\section{PËVZNER, B. NAUMOV, V. PUURA, A. BELENKI}

\section{DISTRIBUTION OF DICTYONEMA SHALE AND ITS SELF-HEATING REGIME IN DUMPS OF MAARDU PHOSPHORITE OPEN-CUT MINE}

The authors present analysis results of the distribution of dictyonema shale in the dumps according to data of radioactive carottage of specially bored cores and other geological and mining-geological documentation, as well as measurements of temperature in the dumped mass at various depths. The regularities of self-heating and self-ignition of shale have been determined as being dependent on the aeration conditions of the dumped mass. 